\title{
INTERDISCIPLINARIDADE NO ENSINO SUPERIOR: ANÁLISE DA PERCEPÇÃO DE PROFESSORES DE CONTROLADORIA EM CURSOS DE CIÊNCIAS CONTÁBEIS NA CIDADE DE SÃO PAULO
}

\author{
Ivam Ricardo Peleias* \\ Janete de FÁtima Mendonça** \\ Vilma GeNI SLOMSKI $* * *$ \\ IVANi CATARInA Arantes FAZENDA $* * * *$
}

Recebido: 14 out. 2010

Aprovado: 22 fev. 2011

*Doutor (1999) e Mestre (1992) em Ciências Contábeis pela Universidade de São Paulo - FEA-USP. Professor e pesquisador do Programa de Mestrado em Ciências Contábeis do Centro Universitário FECAP. Professor Assistente Doutor da Pontifícia Universidade Católica de São Paulo - PUC-SP. São Paulo, Brasil. E-mail: ivamrp@fecap.br

** Mestre (2007) em Ciências Contábeis pelo Centro Universitário FECAP. Professora e Coordenadora do Curso de Graduação em Ciências Contábeis da Universidade Cruzeiro do Sul. São Paulo, Brasil. E-mail: Janete mendonca@hotmail.com

*** Pós-Doutora em Ciências Contábeis, pela FEA/USP, área da Educação e Pesquisa Contábil, com projeto financiado pela FAPESP. Mestre e Doutora em Educação pela FEUSP. Professora e Pesquisadora do Programa de Mestrado em Ciências Contábeis do Centro Universitário FECAP. São Paulo, Brasil. E-mail: vilma.geni@fecap.br

**** Livre Docente em Didática pela UNESP (1991), Doutora em Antropologia pela Universidade de São Paulo (1984), Mestre em Filosofia da Educação pela PUC de São Paulo (1978). Professora titular da PUC de São Paulo, Brasil, professora associada do CRIE (Centre de Recherche et intervention educative) da Universidade de Sherbrooke- Canadá. E-mail: jfazenda@uol.com.br

Resumo: Este estudo buscou conhecer, analisar e descrever a percepção de professores da disciplina de Controladoria em cursos de Ciências Contábeis em Instituições de Ensino Superior - IES - na cidade de São Paulo, sobre a interdisciplinaridade e sua importância na formação dos contadores. É uma pesquisa descritiva-qualitativa, com dados obtidos em entrevistas com sete professores de quatro IES. Verificou-se que a interdisciplinaridade não é adotada de forma explícita no curso e nem nas práticas de seus atores; porém, os docentes percebem sua importância para a prática pedagógica, a melhoria da qualidade de ensino e a formação discente. As falas revelaram trocas informais de ideias e de experiências de ensino no contexto universitário. Os professores mostraram-se preocupados em se inteirar do conjunto de disciplinas, mas mostraram pouco compromisso com uma integração mais planejada e uma prática de ensino compartilhada, tendo o Projeto Político Pedagógico - PPP - como o lócus prático no curso. A interdisciplinaridade é mais pensada e falada do que vivenciada. Conclui-se que, embora os professores sejam sensíveis à importância da interdisciplinaridade na formação dos futuros contadores, persiste uma distância entre o falado, o pensado e o efetivamente praticado no contexto universitário.

Palarvas-chave: Contabilidade. Ensino superior. Brasil.

INTERDISCIPLINARITY IN HIGHER EDUCTION: ANALYSIS OF THE PERCEPTION OF TEACHERS OF MANAGEMENT CONTROL IN ACCOUNTING PROGRAMS IN THE CITY OF SÃO PAULO

Abstract: The aim of this research is to understand, analyze and describe the perception of Controllership professors in accounting undergraduate programs in Universities in the city of São Paulo, concerning the importance of interdisciplinary work in the formation of accountants. It is a descriptive- qualitative research, and its data was obtained by means of an interview with seven professors from 
four universities. It was verified that the interdisciplinary work is not completely adopted in the program. Moreover, it is not adopted by their actors in their practices. However, its importance for the pedagogical practice is perceived by those professors, as well as for enhancing the teaching and the formation of the students. It was also revealed that there is an informal exchange of ideas, as well as an exchange of teaching experience in the university context. It was shown that the professors are preoccupied with taking part in the subjects' context, but have little commitment with a better planned integration and a shared teaching practice, for they only apply the Pedagogical and Political Project - PPP as a focus in the program. Therefore, it can be said that the interdisciplinary work is nothing more than thoughts put into words. It can be concluded that, although those professors perceive the importance of the interdisciplinary work in their students' formation, the distance between thoughts and words still exists in the university context.

Key words: Accountancy. Higher education. Brazil.

\section{INTRODUÇÃO}

Mudanças na conjuntura mundial têm estimulado reflexões sobre o papel da universidade. Sua função não é apenas capacitar os acadêmicos para novos postos de trabalho, mas também para exercerem com consciência a cidadania, e para tal, a autonomia, o senso crítico e o desenvolvimento intelectual são pontos chaves no processo de inserção social e profissional. Esse entendimento reforça a ideia de que a universidade deve zelar pela qualidade do trabalho acadêmico e pela competência dos profissionais que forma, além de priorizar o desenvolvimento de competências, habilidades, valores e conhecimentos em função dos novos saberes que se produzem e exigem um novo perfil profissional.

Quando se questiona o desempenho profissional do formado, é a qualidade do ensino que está em avaliação. Assim caminha a reforma universitária, acerca da qual a LDB (BRASIL, 1996) traz orientações para direcionar o processo de formação humana, por meio da direção e centralização da orientação curricular sob os auspícios do Estado - nos projetos governamentais de escolarização.

A LDB (BRASIL, 1996), em seu capítulo IV, Art. 43º. I., afirma que a finalidade da educação é "estimular a criação cultural e o desenvolvimento do espírito científico e do pensamento reflexivo". No Título I - Da Educação, § $2^{\circ}$, consta que "a educação escolar deverá vincular-se ao mundo do trabalho e à prática social". Isso indica as dimensões da vida ou os contextos valorizados: o trabalho e a cidadania ativa para o exercício consciente dos direitos e deveres, em especial a educação para construção social.

A aquisição de conhecimentos, habilidades, competências e valores dependem de um ensino que faça a ponte entre a teoria e a prática, ligando ciência e trabalho. O Ensino Superior no Brasil tem se guiado pelo paradigma linear e cartesiano, que dissocia o pensamento e a ação; a falta de contato com a realidade parece ser acentuada. Os professores, no esforço de conduzir os alunos a 
aprender, em geral, dão importância ao conteúdo em si, e não à sua interligação com a situação da qual emerge, gerando a dissociação entre teoria e prática.

Para sintonizar a universidade com uma nova ordem mundial, os paradigmas do mundo moderno e a formação científica e tecnológica dos alunos, a LDB (BRASIL, 1996) instituiu a adequação dos cursos de graduação por meio das Diretrizes Curriculares Nacionais (DCN). As DCN superam os currículos mínimos obrigatórios, permitindo uma organização curricular com relativa liberdade e flexibilidade. Essa organização deve prever: a) permeabilidade em relação às mudanças que ocorrem no mundo científico e nos processos sociais; b) a interdisciplinaridade; c) a formação sintonizada com a realidade social; d) a perspectiva de uma educação continuada ao longo da vida; e) a articulação teoria-prática presente na indissociabilidade entre ensino, pesquisa e extensão.

Esses objetivos indicam mudanças trazidas pelas DCN, que pregam a abertura e a flexibilização das grades curriculares. Amplia-se o leque de possibilidades a partir do Projeto Político Pedagógico (PPP) da Instituição de Ensino Superior (IES), que deve assentar-se sobre os conceitos de autonomia acadêmica e flexibilização, tornando-se realidade por meio de um currículo interdisciplinar.

Para a aplicabilidade e efetividade desses conceitos, o PPP deve ser instituído para projetar, lançar, orientar, dar direção às ideias e a processos pedagógicos baseados nas reflexões e ações do corpo docente; é o orientador e condutor do presente e do futuro. Para alguns autores, o qualificativo Político do termo já é assumido pelo adjetivo Pedagógico, pois o projeto busca uma ação de transformação. O PPP é o balizador do fazer universitário, expressando a prática pedagógica das IES e dos cursos e dando direção à gestão e às atividades educacionais.

Falar de PPP não é novidade, posto que sua existência sempre foi conhecida. Porém, a falta de participação coletiva dos docentes na sua elaboração e de clareza na compreensão da ideia de "projeto" favorecem a implantação burocrática e fragmentada. A LDB anterior - Lei 5692/68, solicitava apenas o cumprimento das orientações emanadas do poder central.

Para Siqueira (2003), a elaboração do currículo tradicional baseia-se na "hiperespecialização", o que deveria dar lugar ao "reconhecimento da complexidade do mundo atual", pela superação de limites "epistemológicos, psicossociológicos, institucionais". Para garantir sua empregabilidade, o profissional precisa compreender o mundo, sem se isolar em especializações que, embora lhe permitam exercer a profissão, negam-lhe a competência exigida pelo mundo do trabalho. Nesse sentido, Chaves (2005) assevera que "os grandes desafios humanísticos, científicos e tecnológicos têm quase sempre caráter 
interdisciplinar e somente podem ser resolvidos por equipes de profissionais de diversas áreas".

A nova LDB (Lei 9394/96) defende a colaboração, o trabalho em equipe e a construção de um PPP participativo e colaborativo, originado no seio da coletividade acadêmica, dando identidade à IES e ao curso. "É a configuração da singularidade e da particularidade da instituição educativa" (VEIGA, 2000, p. 187).

É desse ponto de vista que se discute a interdisciplinaridade no curso de Ciências Contábeis. Formar contadores globalizados remete à discussão sobre a construção do PPP do curso e a elaboração de currículos próprios adequados ao cenário atual, em que a formação dos profissionais responda aos desafios que o mundo lhes coloca.

O Ministério da Educação e Cultura (MEC) promulgou a Resolução $n^{\circ}$ 10/2004; em seu artigo $2^{\circ}$, revela a preocupação em atribuir autonomia e flexibilidade ao ensino, e apresenta a proposta de alteração dos currículos dos cursos de graduação em Ciências Contábeis. As IES devem estabelecer a organização curricular por meio de PPP, descrevendo os seguintes aspectos: a) I - perfil profissional esperado para o formando, em termos de competências e habilidades; b) II - componentes curriculares integrantes; c) III - sistema de avaliação do estudante e do curso; d) IV - estágio curricular supervisionado; e) V - atividades complementares; f) VI - monografia, projeto de iniciação científica ou projeto de atividade - como Trabalho de Conclusão de Curso (TCC) - como componente opcional da instituição; g) VII - regime acadêmico de oferta; h) VIII - outros aspectos que tornem consistente o referido projeto.

A descrição dos aspectos do PPP que as IES devem seguir revela a intenção de formar profissionais qualificados. Todavia, sabe-se dos problemas que persistem e impedem que a alteração curricular cumpra a proposta de "atribuir uma autonomia e flexibilidade" sugerida pelas DCN. Marion (1996) em estudos anteriores, abordou as limitações e dificuldades dos alunos quanto à aprendizagem das denominadas "Contabilidades Aplicadas", causadas pela concentração de disciplinas técnicas, restringindo a visão do futuro profissional à escrituração Contábil.

A educação precisa ser entendida e trabalhada de forma interdisciplinar, tendo no aluno um agente ativo. O discente precisa ser comprometido, responsável, apto a planejar ações, assumir responsabilidades, tomar decisões diante dos fatos e interagir em seu meio. Cabe ao professor tornar o aluno um sujeito de sua aprendizagem. Ao ser co-participante do processo, o discente aprenderá a planejar, a trabalhar com hipóteses e a encontrar soluções para os problemas reais. 
Nesse sentido, Luck (2001, p. 64) ressalta que:

A interdisciplinaridade é o processo de integração e engajamento de educadores, num trabalho conjunto, de interação das disciplinas do currículo escolar entre si e com a realidade, de modo a superar a fragmentação do ensino, objetivando a formação integral dos alunos, a fim de que exerçam a cidadania, mediante uma visão global de mundo e com capacidade para enfrentar os problemas complexos, amplos e globais da realidade.

Essa ideia indica a interdisciplinaridade como articuladora do processo de ensino e de aprendizagem, ao se produzir como atitude (FAZENDA, 1979, 1995), modo de pensar (MORIN, 2005), pressuposto na organização curricular (JAPIASSU, 1976), fundamento para as opções metodológicas do ensinar (GADOTTI, 2006) e como elemento orientador na formação dos profissionais da educação.

Para que os novos currículos montados sob o paradigma da complexidade e do pensamento sistêmico sejam eficazes, requer-se uma nova postura institucional, com o envolvimento de docentes e estudantes. Não se pode aceitar o ensino seccionado, departamentalizado, em que disciplinas e professores não se conhecem e não estejam engajados em um projeto coletivo.

Isso remete à reflexão sobre o papel do docente, sobre a prática do ensino superior e sobre a construção de um PPP que concretize os objetivos da IES como produtora do conhecimento científico, formadora de profissionais competentes a serviço da difusão do conhecimento e do desenvolvimento social. É a IES que pode realizar a formação profissional e a integração da ciência à cultura, exigindo que os docentes atuem como educadores.

Considerada a realidade descrita e a necessidade de uma discussão maior sobre a educação universitária oferecer aos acadêmicos referenciais que os ajudem a perceber as várias dimensões dos fatos, em seus aspectos teóricos como práticos, formulou-se a seguinte questão:

Qual é a percepção de professores que ministram a disciplina de Controladoria no curso de Ciências Contábeis em IES do município de São de Paulo, sobre a interdisciplinaridade e sua importância na formação dos contadores?

Ao buscar respostas para essa questão, definiu-se como objetivo conhecer, analisar e descrever a percepção de professores da disciplina de Controladoria em cursos de Ciências Contábeis oferecidos por IES da cidade de São Paulo, sobre a interdisciplinaridade e sua importância na formação dos contadores. 
Objetiva-se contribuir para melhor compreender a temática em questão, auxiliando educadores e IES na ressignificação do trabalho pedagógico em termos de currículo, métodos, conteúdos, avaliação e formas de organização dos ambientes de aprendizagem. Os estudos e pesquisas sobre a questão interdisciplinar podem contribuir para fomentar propostas e posturas metodológicas que atendam às reais necessidades dos alunos, permitindo aprendizagens significativas no contexto universitário.

\section{REVISÃO DA LITERATURA}

\subsection{Origem e conceito da interdisciplinaridade}

A discussão sobre a interdisciplinaridade ocorre do ponto de vista epistemológico e pedagógico, abarcando conceitos diversos e complementares. $\mathrm{Na}$ epistemologia, tomam-se como categorias para estudo o conhecimento em seus aspectos de produção, reconstrução e socialização, a ciência e seus paradigmas e o método como mediação entre o sujeito e a realidade. Aqui, o tema é visto do ponto de vista pedagógico, discutindo-se questões de natureza curricular, de ensino e aprendizagem acadêmica.

Falar de propostas integradoras (interdisciplinares) é um desafio, uma mudança paradigmática em pleno curso. O movimento histórico da presença do enfoque interdisciplinar na Educação é um pressuposto relacionado a um contexto amplo e complexo de mudanças, abrangendo a Educação e outros setores da vida social, como a Economia, a Política e a Tecnologia.

A necessidade da interdisciplinaridade na produção e na socialização do conhecimento na educação é estudada por vários autores, principalmente os que pesquisam as teorias curriculares e as epistemologias pedagógicas. A literatura mostra ao menos uma posição consensual sobre o sentido e a finalidade da interdisciplinaridade: busca responder à necessidade de superação da visão fragmentada nos processos de produção e socialização do conhecimento. É um movimento que caminha para novas formas de organização e socialização do conhecimento em todas as esferas sociais.

Gadotti (2006) informa que a interdisciplinaridade, como um enfoque teórico- metodológico, surge na $2^{\mathrm{a}}$ metade do século XX, em resposta a uma necessidade principalmente nos campos das ciências humanas e da educação: superar a fragmentação e o caráter de especialização do conhecimento, causados pela tendência epistemológica positivista, em cujas raízes estão o empirismo, o naturalismo e o mecanicismo científico do início da modernidade. A influência vem de grandes pensadores modernos como Galileu, Bacon, 
Descartes, Newton, Darwin e outros, indicando que as ciências se dividiram e se especializaram.

Sob esse ponto de vista paradigmático, Moraes (2002) ressalta que a escola atual continua influenciada pelo velho paradigma, submetida a um sistema paternalista, hierárquico, autoritário e dogmático, não percebendo mudanças ao seu redor, muitas vezes resistindo a essas. Persiste a divisão do conhecimento em assuntos, especialidades, sub-especialidades, transformando o todo em partes, separando o corpo da mente, isolando os fatos, sem uma preocupação maior com a integração, a interação, a continuidade e a síntese.

A mesma autora observa a escola centrada no professor e na transmissão de conteúdos; a ênfase é a transmissão, e o sujeito tem um papel insignificante na produção do conhecimento; a educação é tida como instrução e circunscrita à ação da escola; e priorizam-se as situações de sala de aula, com os alunos instruídos pelos professores.

É preciso romper com esse modo de pensar e agir em educação, buscar novas formas de interpretar a realidade, fazer com que a interdisciplinaridade na produção e na socialização do conhecimento seja a ordem. Esse ponto de vista paradigmático considera que a realidade é complexa e requer um pensamento abrangente, multidimensional, capaz de compreender a complexidade do real e construir um conhecimento que considere essa mesma amplitude.

Em síntese, é preciso olhar o mundo como um todo indivisível, no qual todas as partes se integram. A totalidade é o elemento vital de qualquer ponto de vista que surge a partir dessas ideias. Se há movimento, os fenômenos não podem ser separados. Assim, não há a fragmentação e a separatividade que o modelo mecanicista prega, dentro do qual o pensamento do homem fragmenta a sua realidade.

A literatura sobre o tema mostra ao menos o consenso sobre o sentido e a finalidade da interdisciplinaridade: busca responder à necessidade de superação da visão fragmentada na produção e socialização do conhecimento. Para Frigotto (1995, p. 26), a interdisciplinaridade impõe-se pela própria forma de o "homem produzir-se enquanto ser social e enquanto e enquanto sujeito e objeto do conhecimento social".

A educação precisa acompanhar o movimento da sociedade. A organização curricular que isola as disciplinas em realidades estanques, sem conexão, impede a compreensão do conhecimento integrado e, por consequência, uma percepção totalizante da realidade. A interdisciplinaridade, um movimento contemporâneo que emerge na perspectiva da dialogicidade e da integração 
das ciências e do conhecimento, pretende romper com o caráter de hiperespecialização e com a fragmentação dos saberes.

O movimento interdisciplinar surge com maior força nas ciências humanas sociais. A preocupação com uma visão totalizadora da realidade cognoscível e com a consequente dialogicidade das ciências foi estudada primeiramente na filosofia, seguida pelas ciências sociais e pela epistemologia pedagógica. Gusdorf (1967), Piaget (1973) e Vygotsky (1986) são exemplos desse movimento.

Gadotti (1993) ressalta que, atualmente, na teoria, busca-se fundar a interdisciplinaridade na ética e na antropologia, ao mesmo tempo em que, na prática, surgem projetos que reivindicam uma visão interdisciplinar, sobretudo no campo do ensino e do currículo. No Brasil, o conceito de interdisciplinaridade chegou com a obra de Georges Gusdorf, seguida por Jean Piaget. O primeiro influenciou o pensamento de Hilton Japiassu na epistemologia e o de Ivani Catarina Arantes Fazenda na educação.

Quanto à universidade e o surgimento da nova legislação, nota-se o consenso entre professores, associações científicas, gestores educacionais e a população mais instruída de que, diante da velocidade de produção e absorção das inovações científicas e tecnológicas, o atual paradigma de ensino é inviável e ineficaz em todos os níveis, sobretudo no superior. Os atuais currículos transbordam conteúdos informativos em prejuízo aos formativos e fazem com que o estudante saia da graduação com "conhecimentos" já desatualizados, insuficientes para uma ação interativa e responsável na sociedade como profissional ou cidadão.

Diante dessas constatações, as discussões de DCN, por conta das mudanças encetadas pela nova LDB (Lei 9.394/96), tendem a uma formação mais geral do estudante, com a inclusão, nos currículos institucionais, de temas que propiciem a reflexão sobre caráter, ética, solidariedade, responsabilidade e cidadania. Prega-se a abertura e a flexibilização das grades curriculares, a alteração no sistema de pré-requisitos e menos disciplinas obrigatórias. Busca-se maior leque de possibilidades a partir do PPP da IES, a ser necessariamente assentado nos conceitos de autonomia e de interdisciplinaridade.

Quanto à definição da interdisciplinaridade, parece estar em construção. A demanda por uma definição unívoca e definitiva deve ser a princípio rejeitada, por ser proposta construída a partir das culturas disciplinares existentes. Ademais, encontrar o limite objetivo de sua abrangência conceitual significa concebê-la em uma óptica disciplinar. Leis $(2005$, p. 7$)$ assevera que "a tarefa de procurar definições finais para a interdisciplinaridade não seria algo propriamente interdisciplinar, senão disciplinar". 
Para Fazenda (2002, p. 29), a interdisciplinaridade "é a arte do tecido que nunca deixa ocorrer o divórcio entre seus elementos, entretanto, de um tecido bem trançado e flexível". A metáfora revela a dificuldade de definir o termo. Acrescenta que "a interdisciplinaridade jamais se define e jamais se dá a definir. [...] Interdisciplinaridade não se ensina, nem se aprende: vive-se, exerce-se".

Jantsch e Bianchetti (2002) propõem entender o fenômeno mais como prática em andamento do que como exercício orientado de epistemologias e metodologias definidas, discordando da busca de homogeneização da interdisciplinaridade e/ou enquadramento conceitual. Os autores rejeitam ainda a demanda por uma definição unívoca e definitiva, por ser uma proposta feita a partir de culturas disciplinares existentes. Assim, pode-se inferir que a procura por definições "finais" para a interdisciplinaridade não seria algo propriamente interdisciplinar, senão disciplinar.

Essas interpretações permitem pensar que, no campo conceitual, a interdisciplinaridade é uma reação alternativa à abordagem disciplinar normalizadora (no ensino ou na pesquisa) dos vários objetos de estudo. Independentemente das definições de autores, a interdisciplinaridade sempre se situa no campo do pensar a possibilidade de superar a fragmentação das ciências e dos conhecimentos produzidos por elas, em que, simultaneamente, exprime-se a resistência sobre um saber parcelado.

Para Japiassu (1976), a interdisciplinaridade se dá pela intensa troca entre especialistas e pelo grau de integração real das disciplinas em um mesmo projeto. Visa a recuperar a unidade humana, pela passagem da subjetividade para a intersubjetividade. Além disso, recupera a ideia primeira de cultura (formação do homem total), o papel da escola (formação do homem inserido em sua realidade) e o do homem (agente das mudanças do mundo). Mais do que identificar um conceito para interdisciplinaridade, os autores buscam encontrar seu sentido epistemológico, seu papel e suas implicações sobre o processo do conhecer.

A partir do pressuposto de Japiassu (1976), exige-se que as disciplinas, em seu processo constante e desejável de interpenetração, fecundem-se cada vez mais reciprocamente. É preciso complementaridade dos métodos, dos conceitos, das estruturas e dos axiomas sobre os quais se fundam as práticas pedagógicas das disciplinas científicas.

Morin (2005, p. 23), teórico do movimento interdisciplinar, entende que somente o pensamento complexo sobre uma realidade complexa faz avançar a reforma do pensamento na direção da contextualização, da articulação e da interdisciplinarização do conhecimento gerado pela humanidade: 
[...] a reforma necessária do pensamento é aquela que gera um pensamento do contexto e do complexo. O pensamento contextual busca sempre a relação de inseparabilidade e as inter-retroações entre qualquer fenômeno e seu contexto, e deste com o contexto planetário. O complexo requer um pensamento que capte relações, inter-relações, implicações mútuas, fenômenos multidimensionais, realidades que são simultaneamente solidárias e conflitivas (como a própria democracia, que é o sistema que se nutre de antagonismos e que, simultaneamente, os regula), que respeite a diversidade, ao mesmo tempo em que a unidade, um pensamento organizador que conceba a relação recíproca entre todas as partes.

A interdisciplinaridade representa uma nova consciência da realidade, um novo pensar, que resulta em um ato de troca, de reciprocidade e integração entre áreas distintas de conhecimento. Visa à produção de novos conhecimentos e à resolução de problemas, de modo global e abrangente.

Nesse sentido, as abordagens teóricas revelam que o pensamento e as práticas interdisciplinares, nas ciências em geral e na Educação, não questionam a dimensão disciplinar do conhecimento nas etapas de investigação, produção e socialização. O que se propõe é uma profunda revisão de pensamento, que deve caminhar para intensificar o diálogo, as trocas e a integração conceitual e metodológica nos distintos campos do saber.

\subsection{A postura interdisciplinar: considerações críticas}

A interdisciplinaridade é tida como a "poção mágica" que resolveria as seculares mazelas da educação superior. Contra essa postura radical, Morin (2000) assevera que "as disciplinas se fecham e não comungam umas com as outras". Os fatos são postos de forma cada vez mais segmentada, não deixando transparecer sua unidade. As disciplinas buscam soberania territorial e, à custa de magras trocas, as fronteiras confirmam-se em vez de desmoronarem.

Pombo (2003) aponta o equívoco de confundir qualquer trabalho em grupo com interdisciplinaridade:

“[...] é sempre a ideia embrionária - e muito ingênua - de que a simples presença física (ou virtual) de várias pessoas em torno de uma mesma questão criaria automaticamente um real confronto de perspectivas, uma discussão mais rica".

Para que a equipe torne-se interdisciplinar, seus membros devem ultrapassar seus princípios discursivos, as perspectivas teóricas e os modos de funcionamento originais. Fazenda (1996, p. 32) afirma que o ensino interdisciplinar nasce da proposta de novos objetivos e pedagogia, cuja tônica primeira é suprimir 
o monólogo e instaurar uma prática dialógica. A autora aponta obstáculos: a) psicossociológicos e culturais: não é fácil montar uma equipe com uma linguagem comum, pois não se conhece o real significado do projeto interdisciplinar, a falta de formação específica, a situação estabelecida, além do medo de perder prestígio pessoal; b) metodológicos: por exigir questionamento das formas de desenvolvimento do conteúdo das disciplinas, em função do tipo de indivíduo a ser formado e c) materiais: a efetivação da Interdisciplinaridade exige espaço, tempo e previsão orçamentária adequada.

Fazenda (1996, p. 32) alerta para não considerar a interdisciplinaridade uma panaceia que garantirá um ensino adequado ou um saber unificado, mas um ponto de vista para uma reflexão profunda, crítica e salutar sobre o funcionamento do ensino.

Nissani (2006) indica contextos relativos a duas ou mais disciplinas em que a interdisciplinaridade pode ser encontrada: a) no conhecimento interdisciplinar, que requer familiaridade; b) na pesquisa interdisciplinar, que combina componentes na busca de conhecimento novo ou expressão artística e c) na educação interdisciplinar, que combina componentes em um único programa de aprendizagem.

Sob essa visão crítica, a interdisciplinaridade pode ser considerada, segundo Fazenda (2002, p. 32): a) um meio de conseguir melhor formação geral, pois apenas um enfoque interdisciplinar pode permitir a identificação entre o vivido e o estudado, desde que o vivido resulte da inter-relação de várias experiências; b) um meio de atingir uma formação profissional, por abrir novos campos do conhecimento e novas descobertas; c) uma condição para uma educação permanente, já que a inter-subjetividade, característica essencial da interdisciplinaridade, permite a troca contínua de experiências e d) uma forma de compreender e mudar o mundo; como o homem é agente e paciente da realidade do mundo, é preciso um conhecimento efetivo dos vários aspectos dessa realidade.

Schwartzman (1992, p. 197) alerta para o fato de que:

O problema da integração da vida cultural é hoje o de tornar possível que pessoas que vivem em mundos diferentes tenham um impacto genuíno e recíproco umas sobre as outras. Se é verdade que existe algum tipo de consciência geral, ela consiste na interação entre uma multidão de visões não completamente comensuráveis, e a vitalidade desta consciência depende da criação das condições sob as quais esta interação irá ocorrer. E para isto, o primeiro passo consiste, certamente, em aceitar estas diferenças; o segundo em entender em que estas diferenças consistem; e o terceiro em construir um tipo de vocabulário através do qual estas diferenças possam ser formuladas publicamente. 
A interdisciplinaridade exige uma nova visão de escola, criativa, ousada e com uma nova concepção de divisão do saber, que garanta a especificidade dos conteúdos, paralelamente à sua integração em um todo harmonioso e significativo.

\subsection{A Interdisciplinaridade e o ensino da Contabilidade}

A revisão da literatura revela amplo material sobre a interdisciplinaridade e aponta dois fatos significativos: falta de consenso entre especialistas na definição do termo, seguida de uma aplicação rara e assistemática. A aplicação da Interdisciplinaridade nas Ciências Contábeis não é tratada na literatura na dimensão de sua importância. Houve em congressos e periódicos nacionais da área trabalhos e relatos de experiências, confirmando a dificuldade de se localizar literatura específica.

Paiva (1999, p. 93) informa que "a interdisciplinaridade dentro do próprio curso de Ciências Contábeis é praticamente inexistente”. A razão é que os conteúdos/disciplinas são lecionados de forma desarticulada. Ademais, afirma que o aluno não consegue formar uma compreensão global e indivisível da Contabilidade como Ciência, por receber uma visão fragmentada de várias Contabilidades: gerencial, comercial, industrial, pública, bancária, sem integração entre as disciplinas.

Sobre a implementação da Interdisciplinaridade no curso, Silva (2003) enfatiza a atitude do docente, concluindo pela possibilidade de um projeto por eixos temáticos semestrais, tendo uma disciplina como âncora articulada às demais. Destaca que "os desafios foram enormes para implantar o projeto desde a resistência dos alunos e de alguns professores; porém, a vontade de ousar da coordenação fez com que os obstáculos fossem diminuindo com o tempo, pois a dialética do novo e do velho na ação interdisciplinar transformase em inovação". Duas constatações relevantes desse autor são: $1^{\mathrm{a}}$ : incutir nos discentes o gosto pela profissão é uma tarefa árdua; $2^{\mathrm{a}}$ : é difícil empreender ações interdisciplinares, o que requer condições para sua operacionalização.

Pinheiro (2003) ressalta que a aplicação do modelo considera várias etapas: a) preparar a grade curricular; b) estudar a integração horizontal das disciplinas do $1^{\circ}$ e do $2^{\circ}$ período; c) fazer reuniões com os docentes para troca de ideias e estudo conjunto dos programas de disciplina; d) oferecer cursos para melhoria na didática e na Interdisciplinaridade; e) estudar projetos, temas, tópicos, práticas ou pesquisas feitas em aula pelos alunos, com vistas à Interdisciplinaridade; f) controlar o processo pelo orientador pedagógico e pelos professores envolvidos, com avaliações formativas para aferir a aprendizagem; g) fazer aferição final da 
aprendizagem e retroalimentação do sistema na busca de melhores condições de trabalho e evolução profissional do aluno.

O mesmo autor relata a importância do apoio da IES oferecendo condições para a realização do projeto de forma adequada e sustentada, além da participação real dos docentes, que precisam se integrar e se envolver nesse processo de trocas.

Conforme Molinari (2003), sobre a integração entre Contabilidade, Psicologia e Sociologia, "os profissionais da Contabilidade podem se interessar e sentir afinidade pela combinação desta com outra ciência social. Sem abandonar as técnicas contábeis, tais profissionais podem encontrar respostas em outra ciência social para problemas que apenas a Contabilidade não encontra explicação".

Passos (2004) aborda três aspectos sobre Interdisciplinaridade: formas de relacionamento entre as disciplinas, pesquisa e atitude. $\mathrm{O}$ autor trata da percepção de coordenadores dos cursos sobre pesquisa, planejamento pedagógico e grade curricular, e seus estudos revelam a ênfase no mercado de trabalho, o nível baixo de relacionamento entre disciplinas e a relevância para as matérias técnicas contábeis.

Peleias et al. (2008) demonstram as condições de oferta dos conteúdos de Sistemas de Informação nos cursos na cidade de São Paulo, ao identificar como pontos de atenção e ação corretiva a baixa integração entre os docentes do curso, causada pelo comparecimento pontual nos dias e horários das aulas, e a baixa interdisciplinaridade, como uma consequência da pouca interação entre os professores.

Walker (2005) busca interfaces entre Contabilidade e História, definindo Interdisciplinaridade como "qualquer forma de diálogo ou interação entre duas ou mais disciplinas para produzir novas formas de conhecimento". Bloom e Solotoko (2005) relacionam o estudo conjunto de Contabilidade e História como incentivo aos estudantes, enfatizando que os livros contábeis permitem combinar Contabilidade, História e Economia. Afirmam que esses livros promovem ensino interdisciplinar, que o uso de obras históricas estimula o ensino interdisciplinar entre Contabilidade, História e Economia e que os docentes deveriam usar os livros em um contexto histórico.

Padoan e Clemente (2006) apontam a interligação dos conhecimentos contábeis:

a Contabilidade é sustentada por três teorias: mensuração, informação e decisão. [...] para que consiga desempenhar, com competência, seu papel, carecerá do conhecimento de outras áreas, como as relatadas anteriormente, para realizar bem o que pode cada uma das teorias. 
Mostram ainda a importância da Interdisciplinaridade na formação do Contador por meio dos seguintes resultados: prevalência do ensino tecnicista de Contabilidade, predomínio das matérias contábeis e, como conseqüência, visão pouco integradora das disciplinas.

Miranda e Miranda (2006) asseveram que, "no que tange à interdisciplinaridade, é possível aplicar os métodos de ensino para caracterizá-las com estes aspectos, mesmo que estas disciplinas tenham caráter mais técnico". Ademais, ressaltam o relacionamento entre as disciplinas na IES pesquisada, situada no nordeste paulista, reproduzido no quadro 1, abaixo:

\section{Quadro 1 - Relacionamento entre disciplinas}

\begin{tabular}{|l|l|}
\hline \multicolumn{1}{|c|}{ Disciplinas/semestre } & \multicolumn{1}{c|}{ Disciplinas relacionadas/semestre } \\
\hline Contabilidade Geral I $\left(1^{\circ}\right)$ & Informática aplicada I \\
\hline Matemática financeira $\left(3^{\circ}\right)$ & Informática aplicada II $\left(3^{\circ}.\right)$, Matemática aplicada $\left(2^{\circ}\right)$ \\
\hline $\begin{array}{l}\text { Mecanismos de instituições } \\
\text { financeiras }\left(4^{\circ}\right)\end{array}$ & $\begin{array}{l}\text { Matemática financeira }\left(3^{\circ} .\right) \text {, Informática aplicada II }\left(3^{\circ} .\right), \\
\text { Contabilidade financeira }\left(4^{\circ}\right)\end{array}$ \\
\hline Contabilidade avançada $\left(5^{\circ}\right)$ & $\begin{array}{l}\text { Contabilidade geral I, II, III, Economia }\left(2^{\circ}\right) \text {, Matemática } \\
\text { financeira }\left(3^{\circ}\right) \text {, Contabilidade intermediária }\left(4^{\circ}\right) \text {, Análise das } \\
\text { demonstrações contábeis }\left(5^{\circ}\right)\end{array}$ \\
\hline Controladoria $\left(7^{\circ}\right)$ & $\begin{array}{l}\text { Administração geral }\left(1^{\circ}\right), \text { Empreendedorismo }\left(2^{\circ}\right), \text { Informática } \\
\text { aplicada às práticas contábeis }\left(1^{\circ} \text { e } 3^{\circ}\right), \text { Sistemas de } \\
\text { informações gerenciais }\left(3^{\circ}\right), \text { Contabilidade de custos I e II }\left(3^{\circ} \mathrm{e}\right. \\
\left.4^{\circ}\right), \text { Análise das demonstrações contábeis }\left(5^{\circ}\right), \text { Contabilidade } \\
\text { gerencial }\left(6^{\circ}\right) \text {, Orçamento empresarial }\left(7^{\circ}\right)\end{array}$ \\
\hline
\end{tabular}

Fonte: os autores, adaptado de Miranda e Miranda (2006)

O estudo revela maior facilidade em aplicar a Interdisciplinaridade no fim do curso e a importância do docente na sua implementação. Conforme os autores acima, "o curso como um todo já propicia a Interdisciplinaridade de forma espontânea, porém sem o auxílio da instituição, coordenadores e professores, esta prática poderá ficar defasada, ou apenas ser um ponto ilustrativo nas grades curriculares".

\section{UM CAMINHO PARA CAPTAR A PERCEPÇÃO DOS PROFESSORES SOBRE A INTERDISCIPLINARIDADE}

O objetivo da pesquisa foi conhecer a opinião de docentes que ministram a disciplina de Controladoria no curso de Ciências Contábeis em IES da cidade 
de São Paulo. Assim, a análise descritiva e a abordagem qualitativa são os tipos aplicáveis à coleta e análise dos dados (GIL, 2002; LÜDKE; ANDRÉ, 1986, p. 12).

Os sujeitos pesquisados foram professores da disciplina. A justificativa em escolher Controladoria é a sua inter-relação com outras áreas de conhecimento (VATTER, 1950; KANITZ, 1976; CATELLI, 2001; PELEIAS, 2002; NASCIMENTO E REGINATO, 2006), o que pressupõe a necessidade da interdisciplinaridade no curso superior.

Dentre os professores que lecionavam a disciplina nas IES que oferecem o curso, escolheram-se de modo intencional 07 docentes, dos quais um de um Centro Universitário e os outros seis de universidades. A escolha das IES obedeceu a dois critérios: sua importância na oferta de cursos de Ciências Contábeis na cidade de São Paulo e a acessibilidade aos sujeitos entrevistados, todos com o grau mínimo de mestre. A amostra foi formada em função das variáveis que, consideradas estratégicas pelos pesquisadores, são estratégicas para obter exemplos da maior diversidade possível das atitudes sobre o tema em estudo (MICHELAT, 1982, p. 199).

Os dados foram coletados por meio de entrevistas semi-estruturadas (TRIVIÑOS, 1987; ROSA, ARNOLDI, 2006, p. 16). O roteiro das entrevistas possui seis grupos de questões, que buscavam: a) Localizar e analisar a existência da interdisciplinaridade no ensino de Ciências Contábeis, b) Demonstrar a importância da Interdisciplinaridade como integradora de conhecimento e c) Levantar a percepção da Interdisciplinaridade pelos docentes de Controladoria no curso de Ciências Contábeis em IES da cidade de São Paulo. Por meio das questões, buscou-se que os entrevistados expressassem seu modo de pensar ou de agir face aos temas focalizados, estimulando a oportunidade de investigar crenças, sentimentos, valores, razões e motivos acompanhados de fatos e comportamentos, em uma captação da fala dos sujeitos na íntegra (BIASOLI ALVES; DIAS DA SILVA, 1992, p. 6). As entrevistas foram gravadas, transcritas e analisadas.

Para a análise dos dados, aplicou-se a análise de conteúdo (BARDIN, 2004, p. 7; FRANCO, 2005, p. 23; LAVILLE, DIONNE, 1999, p. 216). As respostas foram analisadas considerando-se os grupos estabelecidos no roteiro de entrevista; observando-se a preocupação com a análise das mensagens; fazendo com que refletissem os objetivos da pesquisa; tendo como apoio os indícios manifestos nas entrevistas; a relevância teórica das informações/ mensagens relacionadas aos objetivos desta pesquisa e o encaminhamento qualitativo. 


\section{APRESENTAÇÃO E DISCUSSÃO DOS RESULTADOS}

\subsection{Perfil dos professores colaboradores do estudo}

Participaram da pesquisa sete docentes da disciplina de Controladoria de quatro IES da cidade de São Paulo, graduados em Ciências Contábeis, Administração e em Economia. Cinco possuíam Mestrado em Ciências Contábeis e dois em Administração. Quatro possuíam Doutorado em Ciências Contábeis e dois estavam cursando, um em Comunicação Social. Os sujeitos estavam muito mais dedicados à docência universitária, sendo essa a sua primeira opção de atuação profissional.

\section{2 $O$ que pensam os docentes sobre o curso e a preparação para o mundo do trabalho}

Procurou-se saber se a graduação havia propiciado aos sujeitos os conhecimentos e as habilidades requeridas para a inserção social e profissional. Perguntou-se: "Na sua opinião, a Graduação o preparou suficientemente para o exercício profissional? ”. As falas revelam pouca integração entre os mundos da academia e do trabalho:

Eu vejo a graduação como um processo, um início de processo de formação que visa suprir essa necessidade, teórica e técnica. A prática, infelizmente, acho que a gente está ainda muito distante de resolver todos os problemas da realidade, até porque a nossa área de Contabilidade é muito ampla.

[…]

Para o mercado profissional fora da docência, eu acho que a academia, a graduação, visa dar um componente que é a formação teórica e técnica. No fundo, aliada à prática, é que vai complementar a formação profissional.

Como fiz Administração, a preparação que trouxe da graduação está muito mais voltada à questão do relacionamento pessoal, a questão do bom senso, da visão do que é Administração. Do ponto de vista técnico, muito pouco. Muito pouco mesmo.

As falas indicam que o curso carece de reformulação dos currículos para maior integração entre as disciplinas e maior articulação entre o pensamento e a prática Contábil. Esses dados confirmam o que Passos (2004) observou, ao apontar que o curso enfatiza o mercado de trabalho, com relevância para as matérias técnicas contábeis e um nível baixo de relacionamento entre disciplinas. 
Essa realidade presente no curso não atende as necessidades de formação dos alunos. Isso indica que a Ciência Contábil precisa evoluir para acompanhar as mudanças econômicas, sociais, culturais e políticas mundiais, o que torna necessário e urgente uma melhora no ensino da contabilidade.

Nessa direção caminha a Resolução $n^{0}$ 03/92, que pretende considerar a região de atuação das IES, o perfil do profissional a ser formado e o conteúdo programático. A comissão autora da proposta de alteração curricular revela preocupação em atribuir autonomia e flexibilidade ao ensino de contabilidade no Brasil.

Assim, buscou-se identificar a relação entre o ensino de Ciências Contábeis e o preparo para a atuação profissional com base nas prerrogativas estabelecidas pela Resolução $n^{\circ}$ 560/1983, do CFC - Conselho Federal de Contabilidade. Perguntou-se: "Na sua opinião, o curso proporciona ao aluno o exercício de todas as prerrogativas profissionais estabelecidas pelo Conselho Federal de Contabilidade, por meio da Resolução 560/1983?" As respostas revelam duas categorias: a) percepção quanto ao exercício das prerrogativas profissionais estabelecidas e b) percepção da extensão do exercício profissional além das prerrogativas:

De certa forma, sim. Mas é pouco.

[...]

Os cursos têm que preparar não para exercer as prerrogativas da profissão, mas para exercer o potencial que o Contador tem que ter. Esse Contador não pode ser um Contador restrito a uma visão pequena da profissão ainda. Ele tem que crescer. Tem que crescer para ocupar o espaço de um verdadeiro Gestor. Porque ele é o melhor preparado do que todos os outros para ser um Gestor. É preciso evoluir. É preciso que nós dos cursos consigamos dar isso, que consigamos dar essa visão.

.. $[\ldots]$

Todas? Eu não me lembro quais são, mas eu imagino que seja lá Auditoria, Perícia, trabalhar em órgãos públicos. Olha, eu acho que o mercado, ele faz uma pré-seleção. Por mais que a gente possa ensinar uma coisa, para o exercício, o aluno ele tem que fazer uma escolha de carreira.

[...]

Também acho que existem os cursos de especialização para isso, para fazer um aprofundamento na vocação que ele escolheu. Mas eu acho que dá para eles fecharem balanço, essas coisas, só que o mercado mesmo não atribui essa responsabilidade imediatamente para ele porque tem o desenvolvimento natural do aprendizado lá na empresa. 
Pelas respostas, conclui-se que os entrevistados concordam que as prerrogativas profissionais estabelecidas pelo Conselho Federal de Contabilidade vêm sendo atendidas pelos cursos de Ciências Contábeis.

\subsection{A percepção dos professores sobre o PPP e o currículo do curso}

O PPP é o elemento integrador e agregador de valor ao curso de graduação, e não se resume a um documento de dimensão pedagógica, “[...] nem muito menos ao conjunto de projetos e de planos isolados de cada professor em sua sala de aula [...]" (VEIGA, 2006, p. 11). É um documento que reflete a realidade da IES, “[...] situada em um contexto mais amplo que a influencia e que é por ela influenciado. Em suma, é um instrumento clarificador da ação educativa da instituição em sua totalidade" (VEIGA, 2006, p. 12).

Nessa direção, procurou-se saber se os sujeitos conheciam e estavam engajados na construção do PPP do curso em que atuavam. Perguntouse: "Você conhece o PPP do curso de Ciências Contábeis da IES em que trabalha? Teve participação, de alguma forma, em sua construção ou estruturação?" "O PPP é disponibilizado para todos os professores do curso? De que forma?". As falas a seguir reproduzem as respostas da maioria dos sujeitos para as categorias de conhecimento: participação e disponibilização, relativas ao PPP:

Conheço o projeto que está em vigor e o que está sendo implantado.

[...]

Pela própria função que exerço, tenho que coordenar os professores e porque realmente eu acredito que possa contribuir com coisas positivas. Então tem um grande desejo e vontade e participo sim.

[...]

O projeto pedagógico está disponivel para os professores. Existe departamento que disponibiliza sempre que querem. O que acontece é que as passagens são tantas nos órgãos colegiados, que acaba se tornando um projeto muito extenso, e onde a consulta acaba sendo prejudicada. O que a gente costuma fazer, é a essência do trabalho a gente disponibiliza.

Essas falas revelam que os sujeitos conhecem o PPP das IES em que trabalham e participaram de alguma forma de sua elaboração. Revelam também que, na maioria das IES pesquisadas, o PPP está parcialmente disponível 
para os professores; não há momentos específicos de encontros entre os docentes para discutir ações relativas ao PPP, e espera-se que o professor tenha a iniciativa de conhecê-lo, não havendo uma discussão específica desse documento.

É necessária uma adequação curricular dos cursos de Ciências Contábeis que propicie a formação desejada ao futuro Contador. Para Paiva (1999, p. 93), "a interdisciplinaridade dentro do próprio curso de Ciências Contábeis é praticamente inexistente”. A razão é que os conteúdos/disciplinas são lecionados quase totalmente de forma desarticulada. Para o autor, o aluno não consegue formar uma compreensão global e indivisível da Contabilidade como Ciência, por receber uma visão fragmentada, de várias Contabilidades, já apontada, sem integração entre as disciplinas.

Nesse sentido, buscou-se a opinião dos sujeitos em vista da melhoria do curso. Perguntou-se: "Você acha que o curso, de maneira geral, poderia ser melhorado? De que forma?" As respostas permitem identificar a postura dos professores frente ao PPP do curso, apontando formas de melhorar o curso, aproximar-se de uma postura interdisciplinar e melhorar a qualidade do ensino Contábil:

[...] eliminação dessas disciplinas que não deram certo (EAD) e substituir por disciplinas que sejam encaradas pelos professores e pelos alunos com mais seriedade.

[...] possibilidade de avaliação do nosso curso, do nosso professor e dos nossos alunos.

A possibilidade de ter uma integração melhor com a Pós-Graduação.

[...] começar a colocar os nossos professores na carreira. Portanto, ter as disciplinas muito mais concatenadas com as linhas definidas pelo MEC. Então tem que ter uma visão extremamente dentro das determinações acadêmicas.

Os dados evidenciam um pensamento unânime dos sujeitos sobre a qualidade da educação Contábil. É consenso que a possibilidade de melhoria do curso está na construção do PPP; todos os entrevistados indicam melhorias a serem feitas no PPP; quatro indicam que, além dessas melhorias, outras devem ser efetuadas no trabalho do professor que diretamente participa do desenvolvimento do PPP em sala de aula.

Os dados confirmam o que diz Veiga (1995) sobre o PPP, quando observa que essa construção é uma ação intencional, com um sentido explícito e um 
compromisso defendido coletivamente. O PPP é também político por estar intimamente articulado ao compromisso sociopolítico e aos interesses reais e coletivos da população majoritária. É político no sentido de ter compromisso com a formação do cidadão para um tipo de sociedade. Na dimensão pedagógica, reside a possibilidade da efetivação da intencionalidade da universidade, que é a formação do cidadão participativo, responsável, compromissado, crítico e criativo. Pedagógico, por definir as ações educativas e as características necessárias às escolas de cumprirem seus propósito e sua intencionalidade (VEIGA, 1995).

\subsection{A percepção dos professores sobre a interdisciplinaridade}

A interdisciplinaridade é uma questão complexa que requer mudança de atitudes acima de tudo. Assim, procurou-se saber a opinião dos entrevistados sobre esse posicionamento a ser adotado no curso e na prática de ensino dos professores. Perguntou-se: "O que você pensa ou entende em relação ao termo Interdisciplinaridade?" As respostas revelam a compreensão e a importância dessa postura dos docentes:

[...] Relação entre as diversas Ciências e das situações acima das Ciências. Na nossa visão miope de anteriormente, não notávamos que as outras ciências tinham que ser usadas na nossa Ciência.

[...]

[...] trabalho conjunto entre diversas disciplinas que de alguma forma se conversam, têm algum tipo de relacionamento para possibilitar uma integração de conteúdos e a não repetição dos mesmos [...]

[...]

[...] Não dá para se fazer bom Contador sem o Direito, sem Matemática, sem a visão econômica.

As falas revelam a ambiguidade e a dificuldade em definir o termo, identificada na revisão de literatura. Os exemplos citados demonstram que os entrevistados intuem mais do que conhecem e vivenciam a interdisciplinaridade, o que confirma a teoria pesquisada sobre a indefinição do termo.

No quadro 2, a seguir, são transcritos trechos da revisão da literatura sobre a indefinição do termo, comparadas com algumas respostas obtidas: 


\section{Quadro 2 - Análise comparativa - base conceitual x entendimento dos entrevistados sobre a interdisciplinaridade}

\begin{tabular}{|c|c|}
\hline $\begin{array}{l}\text { Autores citados na } \\
\text { Revisão da Literatura }\end{array}$ & Entendimentos dos entrevistados \\
\hline $\begin{array}{l}\text { "[...] é a arte do tecido que nunca deixa } \\
\text { ocorrer o divórcio entre seus elementos, } \\
\text { entretanto, de um tecido bem trançado e } \\
\text { flexível". (FAZENDA, 2002, p. 13) } \\
\text { O termo Interdisciplinaridade não pos- } \\
\text { sui ainda um sentido único e estável e, } \\
\text { embora as distinções terminológicas } \\
\text { sejam inúmeras, o principio é sempre o } \\
\text { mesmo: caracteriza-se pela intensidade } \\
\text { das trocas entre os especialistas e pela } \\
\text { integração das disciplinas num projeto } \\
\text { de pesquisa. (FAZENDA, 2002, p. 31) } \\
\text { Mann (2002, p. 1) informa que "a } \\
\text { definição é múltipla e complexa.[...] Ne- } \\
\text { nhuma prática é perfeita, nenhuma for- } \\
\text { ma abrange tudo. Mesmo a promessa } \\
\text { da interdisciplinaridade causa vertigem: } \\
\text { aponta horizontes selvagens, descon- } \\
\text { hecidos, desafia as disciplinas, unifica } \\
\text { o conhecimento, resolve problemas, } \\
\text { muda o mundo. Os entusiastas vêem } \\
\text { a interdisciplinaridade como a onda } \\
\text { do futuro; os céticos a consideram um } \\
\text { modismo. (Tradução livre dos autores). }\end{array}$ & $\begin{array}{l}\text { "Aquela relação entre as diversas Ciências e das } \\
\text { situações acima das Ciências.." } \\
\text { "É o relacionamento com outras áreas do con- } \\
\text { hecimento". } \\
\text { "Eu acho que essa conjunção de assuntos e de } \\
\text { conteúdos, que você usa para um determinado } \\
\text { objetivo, eu acho que isso é interdisciplinaridade. } \\
\text { Agora é difícil o aluno entender isso e o professor } \\
\text { também entender isso. Às vezes eu acho até que } \\
\text { não precisa entender". } \\
\text { "Interdisciplinaridade ou multidisciplinaridade. } \\
\text { São duas palavras da moda, mal usadas e } \\
\text { pouco realizadas ao meu singelo conhecimento } \\
\text { sobre isso." } \\
\text { "E é difícil falar o que é interdisciplinaridade. É } \\
\text { mais fácil falar o quer não é". } \\
\text { "É mais bonito colocar lá, meu curso é inter- } \\
\text { disciplinar mas e daí? Eu entendo interdisci- } \\
\text { plinaridade que é a multidisciplinaridade é } \\
\text { você pegar um outro, fora da própria área do } \\
\text { conhecimento. Quer dizer, você fazer um estudo } \\
\text { multidisciplinar..". } \\
\text { Talvez até eu mesmo não saiba bemo que é mas, } \\
\text { a importância maior é você entender de fato e } \\
\text { fazer valer. Então, ser interdisciplinar no curso é } \\
\text { cair as barreiras. Se a gente conseguir entender } \\
\text { só isso já é uma grande coisa". }\end{array}$ \\
\hline
\end{tabular}

Parte das respostas revela outro aspecto da revisão da literatura, sobre a integração das disciplinas. A análise comparativa está no quadro 3, a seguir: 


\section{Quadro 3 - Análise comparativa - entendimento dos entrevistados sobre a integração entre disciplinas $x$ abordagem constante na revisão da literatura}

\begin{tabular}{|c|c|}
\hline Autores citados na Revisão da Literatura & Entendimento dos entrevistados \\
\hline $\begin{array}{l}\text { Interação existente entre duas ou mais discip- } \\
\text { linas. Esta interação pode ir desde a simples } \\
\text { comunicação das idéias até a integração } \\
\text { mútua dos conceitos directivos, da epistemo- } \\
\text { logia, da terminologia, da metodologia, dos } \\
\text { procedimentos, dos dados e da organização } \\
\text { da investigação e do ensino correspondentes. } \\
\text { (Berger). (POMBO, 2005) } \\
\text { Integração interna e conceptual que rompe } \\
\text { a estrutura de cada disciplina para construir } \\
\text { uma axiomática nova e comum a todas elas } \\
\text { com o fim de dar uma visão unitária de um } \\
\text { sector do saber (Palmade). (POMBO, 2005). } \\
\text { [...] “interdisciplinaridade é normalmente } \\
\text { definida [...] como princípios de interação, } \\
\text { para demonstrar o processo como interagem } \\
\text { as disciplinas". (KLEIN, 1990, p. 55) }\end{array}$ & $\begin{array}{l}\text { "[...] é o trabalho conjunto entre diversas disci- } \\
\text { plinas que de alguma forma se conversam, tem } \\
\text { algum tipo de relacionamento para possibilitar } \\
\text { uma integração de conteúdos e a não repetição } \\
\text { dos mesmos..". } \\
\text { "[...] mas a interdisciplinaridade, significa conteú- } \\
\text { dos que são comuns. E daí a interdisciplinaridade } \\
\text { disso é a integração de conteúdos, uma proposta } \\
\text { de, não só de integração, mas ter uma visão do } \\
\text { todo e não fragmentada..". } \\
\text { "Essa conjunção de assuntos e de conteúdos, } \\
\text { que você usa para um determinado objetivo, eu } \\
\text { acho que isso é interdisciplinaridade". }\end{array}$ \\
\hline
\end{tabular}

\subsection{A prática da interdisciplinaridade no contexto universitário}

A adoção de uma postura interdisciplinar pelos entrevistados foi outra questão que se procurou levantar com este estudo. Perguntou-se: "No desenvolvimento do curso de Ciências Contábeis na IES em que trabalha, poderia destacar algumas ações ou atividades pedagógicas?"; "Existem atividades ou ações que considera interdisciplinares na IES em que ministra suas aulas? Poderia descrevê-las?; "Você percebe os resultados obtidos destas atividades junto aos alunos?; Que resultados poderia destacar?”.

As respostas revelam duas categorias identificadas na maioria dos entrevistados: a) atividades práticas e ações consideradas interdisciplinares e b) resultados dessas ações no processo de ensino-aprendizagem. Seguem as falas dos sujeitos:

Tem uma ferramenta que eu considero bastante interessante e a gente chama aqui de TOP que é a sigla para TIMES DE ORGANIZAÇÃO PEDAGÓGICA. São grupos de disciplinas que guardam essa interdisciplinaridade, pelo menos deveriam guardar. 


\section{$[\cdots]$}

Tem um grupo de disciplinas, por exemplo, que é Contabilidade Gerencial e Societária. Ele agrupa várias disciplinas que estão relacionadas à Contabilidade Gerencial e Societária, então envolve Controladoria, Custos, Contabilidade Gerencial, Administração Financeira e por ai vai.

$[\cdots]$

Os alunos têm a obrigatoriedade de no último ano estar escrevendo um artigo mas não me lembro, eu acho que não existe nenhuma ação conjunta com os alunos. Essa ação se restringe mais ao grupo de professores.

[…]

Além desse aspecto que a gente já abordou da questão dos conteúdos, no time ao qual a Controladoria estratégica pertence, os professores que trabalham com essas disciplinas são os mesmo há alguns anos. Então isso acaba permitindo que muitas vezes a gente faça um rodízio de conteúdos.

[...]

Eu acho que a coisa acontece muito bem no corpo docente. Mas na realidade o que a gente passa para o discente é essa segurança e esse conforto de que os professores se conversam.

A partir da necessidade de processos formativos com a criação de espaços nos quais os professores se encontrem e discutam os problemas pedagógicos e didáticos, perguntou-se: "A IES proporciona encontros entre os professores para discussão de atividades ou ações interdisciplinares?"; "Você identifica obstáculos para se levar adiante uma prática interdisciplinar no curso de Ciências Contábeis?"

As respostas da maioria revelam as seguintes categorias: a) frequência dos encontros e b) principais dificuldades ou obstáculos à participação:

Faz, no mínimo uma vez por semestre. A gente tem alguns fóruns de discussões. A gente tem os encontros dos professores motivados pela coordenação do cursos, às vezes a gente tem os encontros de professores motivados pela própria reitoria. $[\cdots]$

Do ponto de vista formal, a gente tem uma reunião, no mínimo, uma vez por semestre, isso quando a reitoria não faz mais uma. A gente tem encontros mais informais. [...] 
Vejo algumas dificuldades, que eu acho que aqui no nosso curso, felizmente a gente, talvez, não tivesse que é, por exemplo, eu trabalhava numa outra IES maior, com uma condição de trabalho não tão boa quanto a daqui e a gente tinha graves problemas. As pessoas até tinham intenção de fazer um trabalho interdisciplinar, mas ela tinha uma rotatividade de professores muito grande. Essas atividades não resistiam a essas constantes trocas de professores. Já aqui a gente não tem esse problema.

No quadro 4, abaixo, são listadas as dificuldades e os obstáculos apontados pela maioria dos sujeitos, contrapostos a dificuldades, e os obstáculos apontados na revisão da literatura:

\section{Quadro 4 - Dificuldades e obstáculos percebidos pelos entrevistados $\mathrm{x}$ algumas dificuldades e obstáculos apresentados na revisão da literatura}

\begin{tabular}{|c|c|}
\hline $\begin{array}{l}\text { Obstáculos identificados } \\
\text { na revisão da Literatura }\end{array}$ & Obstáculos ou dificuldades apontados \\
\hline $\begin{array}{l}\text { [...] Psicossociológica e cultural: montar } \\
\text { uma equipe com uma linguagem comum } \\
\text { é difícil, pois há o desconhecimento do } \\
\text { real significado do projeto interdisciplinar, } \\
\text { a falta de formação específica, a situação } \\
\text { estabelecida e o medo de perder prestígio } \\
\text { pessoal". (FAZENDA, 1996, p. 32) } \\
\text { "O problema da integração da vida cultural } \\
\text { é hoje o de tornar possível que pessoas que } \\
\text { vivem em mundos diferentes tenham um } \\
\text { impacto genuíno e recíproco umas sobre } \\
\text { as outras. Se é verdade que existe algum } \\
\text { tipo de consciência geral, ela consiste na } \\
\text { interação entre uma multidão de visões } \\
\text { não completamente comensuráveis, e } \\
\text { a vitalidade desta consciência depende } \\
\text { da criação das condições sob as quais } \\
\text { esta interação irá ocorrer. E para isto, } \\
\text { o primeiro passo consiste, certamente, } \\
\text { em aceitar estas diferenças; o segundo } \\
\text { em entender em que estas diferenças } \\
\text { consistem; e o terceiro em construir } \\
\text { um tipo de vocabulário através do qual } \\
\text { estas diferenças possam ser formuladas } \\
\text { publicamente. (SCHWARTZMAN, 1992, } \\
\text { p. 197). }\end{array}$ & $\begin{array}{l}\text { "Existem dificuldades definidas por políticas e } \\
\text { por situações de defesa de grupos de interesse. } \\
\text { Então para que a interdisciplinaridade seja } \\
\text { aplicada na integralidade é preciso que a gente } \\
\text { se destitua desses conceitos de proteção ao } \\
\text { grupo, mas que os outros também o façam". } \\
\text { [...] } \\
\text { "Você sempre tem a noção de poder. Você tem } \\
\text { uma área predominante, ela tem o poder. Você } \\
\text { tem uma área emergente, ela quer um espaço. } \\
\text { Você vai vivenciar isso em qualquer programa". } \\
\text { [...] }\end{array}$ \\
\hline
\end{tabular}


A leitura do quadro 4 revela que, para os docentes, a prática da interdisciplinaridade ocorre de forma lenta e nem todos se engajam, indicando que a prática exige formação, na forma apontada pela revisão da literatura.

Sobre a integração curricular, procurou-se identificar a percepção do professor em relação às áreas de conhecimentos relacionadas à Controladoria e se a disciplina facilita a integração da Contabilidade com outras Ciências ou áreas de conhecimento. Perguntou-se: "Na sua opinião, o curso de Ciências Contábeis proporciona a integração da Contabilidade com outras Ciências? Você acha que por meio da Controladoria essa integração é facilitada?"; "Na sua opinião, quais áreas de conhecimento que mais se relacionam com a Contabilidade?"

As falas a seguir evidenciam o pensamento dos professores, que entendem que a disciplina engloba e se relaciona diretamente com outras disciplinas, tais como orçamento e outras práticas de gestão:

Acho que pela Controladoria, pelo orçamento, análise do orçamento, é mais fácil. São disciplinas que se utilizam das outras ciências para poder tomar as decisões. Então, por excelência, elas podem facilitar.

$[\ldots]$

Essas disciplinas de Gestão, de gerenciamento, que é um conjunto delas éo grande futuro do Contador.

[…]

Falta também uma visão de disciplinas de maior envolvimento, disciplinas que trabalhem com elemento humano, com talento humano. Isto também precisa para nossos contadores. Precisamos saber dominar um pouco mais estas disciplinas, estas Ciências Sociais.

[...]

Acho que poderia ser melhor. Acho que ainda falta. Acho que ainda existe um certo estigma da categoria que precisa ser superado. Acho que às vezes, o próprio Contador não se dá conta do valor que tem, do tipo de atuação que poderia ter. Isso acaba, de uma certa forma, impedindo que a gente faça uma ponte, por exemplo, com Administração Geral, com Economia e outras áreas mais afins, quiçá com outras que são mais distantes como Comunicação, Psicologia porque acho importante quando você trabalha o universo empresarial. 
As respostas revelam que as áreas de conhecimento mais relacionadas à Controladoria são: Administração, Psicologia, Economia e Direito e, em menor proporção, Comunicação, Marketing, Métodos Quantitativos, Sociologia, Antropologia, Filosofia e Engenharia de Produção. Esses resultados confirmam as assertivas de Vatter (1950), Kanitz (1976), Catelli (1999) e Peleias (2002).

\subsection{A prática da interdisciplinaridade no contexto da sala de aula}

Em relação a uma postura pedagógica, ou uma prática de ensino interdisciplinar, perguntou-se: "Você poderia identificar algumas atitudes que considera importantes no professor de Contabilidade?"; "Dentre as atitudes que listou, você acha que alguma merece destaque em termos de melhoria ou aprimoramento por parte do professor?"

A maioria das respostas revela uma categoria de atitudes do professor de Contabilidade consideradas importantes. Seguem as falas dos entrevistados:

A primeira atitude importante para o professor, tem que ser a responsabilidade de identificar, de procurar identificar e avaliar aquilo que o aluno sabe e que a avaliação não seja por aquilo que o aluno não sabe, mas exatamente pelo oposto. E que a avaliação do aluno seja a própria avaliação do professor. Quer dizer, o professor pode dar uma prova extremamente dificil mas ele precisa tomar consciência de que a prova foi extremamente difícil

Não é um posicionamento de transferência de informação tão somente, mas de envolvimento com aquela relação de ensinar e aprender. Então quer dizer, o professor ensina mas aprende, o aluno aprende mas ensina. Então isso nós temos que ter claro.

[...] ele tem que ter a humildade de procurar sempre, de buscar, de aprender.

[...] é ter consciência que você não vai explicar uma prática mecânica, mas você tem que contribuir com o desenvolvimento de um raciocínio. Ele tem que evoluir com o raciocínio. Ele não vai responder debita e credita por isso e por aquilo mas ele tem que raciocinar porque este procedimento, porque está debitando ou creditando.

A interdisciplinaridade requer um modelo de educação baseado no trabalho colaborativo, a troca de experiência entre os docentes em processos formativos que resultem em uma prática de sala de aula em que esteja presente o diálogo. 
É preciso criar espaços e situações de ensino e aprendizagem mediados por instrumentos e linguagens por meio dos quais o professor e os alunos sejam sujeitos do ato de aprender. Assim, perguntou-se: "Como você acha que deve ser a relação aluno-professor?"; "Como você acha que deve ser a relação professor-professor?"

As respostas da maioria dos sujeitos revelam as seguintes categorias: a) formas de relacionamento entre aluno e docente e b) formas de relacionamento entre docentes:

De respeito. De igualdade. Não pode existir essa relação de distanciamento da cátedra à carteira. Tem que haver uma proximidade e uma cumplicidade. Que esta relação de aprender não pode ser o professor contra o aluno, mas de professor junto com o aluno e o aluno junto com o professor.

$[\cdots]$

Hoje em dia se estimula, sob o pretexto da concorrência, uma luta entre professores, muitas vezes até transgredindo os princípios da ética. Então o professor se julga no direito de acusar o outro pelo fato do outro não ter agido da maneira adequada. Isso é absurdo.

$[\cdots]$

Por que eu procuro a falha no meu colega? Por que eu estou com medo que ele vá tomar o meu lugar. Então a minha insegurança, me faz inseguro.

$[\ldots]$

Então tem que ser de muito respeito, de colaboração, de compreensão e de ajuda mútua. E principalmente do envolvimento dos professores, todos, com o curso, com aquele ensino que estão passando.

Os dados indicam uma vontade de mudança das práticas de ensino, fato que carece da implantação de processos formativos dos professores em serviço, isto é, na própria IES. Uma postura interdisciplinar acontece com a adoção de uma pedagogia de projetos. O trabalho com projetos é colaborativo, professoresprofessores e professores-alunos com projetos elaborados em parceria, com o efetivo interesse das partes em ter êxito, evitando assim as rotineiras aulas expositivas.

Quando os projetos são construídos de acordo com as necessidades dos alunos, voltados à aquisição de determinados conhecimentos, é de se esperar que haja motivação. Nesse processo, o aluno aprende descobrindo e construindo o 
seu próprio saber, sendo sujeito ativo, participativo e autônomo na consecução dos seus objetivos.

Essa atitude relaciona-se com a compreensão mais abrangente do processo de ensino e aprendizagem e sua valorização no ensino superior, com a ênfase dada ao aprendiz como sujeito do processo, com o incentivo à pesquisa na graduação e com as mudanças na forma de comunicação. A docência existe para que o aluno aprenda, assim, a ênfase deve ser nas suas ações. A aprendizagem desejada engloba conhecimentos necessários, habilidades e valores a serem vividos, e não há como se promover essa aprendizagem sem a participação e parceria dos aprendizes.

\section{CONCLUSÕES OU ABERTURA PARA NOVAS DISCUSSÕES}

Procurou-se discutir e analisar a interdisciplinaridade na formação de Contadores no ensino superior, a partir da percepção de professores de cursos de Ciências Contábeis em IES da cidade de São de Paulo. Verificou-se que a interdisciplinaridade não está inserida de forma clara no curso e nem nas práticas de seus atores; porém, os docentes percebem sua importância para a eficácia da prática pedagógica e melhoria da qualidade de ensino.

Os resultados apontam que, na percepção dos entrevistados, a integração ocorre sob duas óticas: uma endógena, aproximando as disciplinas do currículo; e outra exógena, aproximando as Ciências Contábeis das demais áreas de conhecimento. As respostas revelam que Administração, Psicologia, Economia e Direito e, em menor proporção, Comunicação, Marketing, Métodos Quantitativos, Sociologia, Antropologia, Filosofia e Engenharia de Produção são as áreas de conhecimento que mais se relacionam com a Contabilidade.

Constatou-se que a Controladoria tem uma característica integradora por excelência, fato revelado pela seguinte fala: "Eu acho a Controladoria o espaço mais interdisciplinar que temos na Contabilidade", confirmada pela revisão da literatura. Os autores foram unânimes em afirmar a característica integradora da Controladoria.

Os dados da percepção dos professores de Controladoria em IES da cidade de São Paulo sobre a interdisciplinaridade revelam que essa postura está mais na intuição do que na efetivação. Os sujeitos mostraram conhecimento ainda incipiente sobre essa postura na sala de aula e no contexto escolar. Entretanto, a insegurança e o senso comum prevalecem na maioria das falas, em frases como "acho que...", "é difícil definir interdisciplinaridade". Essas falas foram 
seguidas, na maioria das vezes, da comunicação de um entendimento próximo do identificado na revisão da literatura.

A percepção dos sujeitos sobre a interdisciplinaridade se revelou incipiente, não se distanciando da literatura, traduzindo uma atuação interdisciplinar reduzida. É o que Pombo (2003) aponta como o equívoco de se confundir qualquer trabalho em grupo com interdisciplinaridade: "[...] é sempre a ideia embrionária - e muito ingênua - de que a simples presença física (ou virtual) de várias pessoas em torno de uma mesma questão criaria automaticamente um real confronto de perspectivas, uma discussão mais rica".

A fala de um sujeito revelou a troca informal de ideias na sala dos professores sobre o trabalho de um colega em aula. Essa constatação revela preocupação do docente em se inteirar do conjunto de disciplinas, mesmo que superficialmente, indicando pouco compromisso com uma integração pensada, construída em conjunto. Essa e outras respostas revelam a inexistência da intensidade de trocas entre os especialistas e da integração das disciplinas em um projeto de pesquisa, projeto esse normalmente ausente das respostas de alguns entrevistados.

A revisão da literatura e as falas dos sujeitos apontam que os principais obstáculos à efetivação de projetos interdisciplinares nas IES pesquisadas estão no próprio professor: resistência a abrir mão do poder de sua disciplina, falta de tempo para participar de projetos, falta de preparo pedagógico em sua formação na área, entre outros. Essas constatações ensejam a oportunidade de novas pesquisas.

Embora um sujeito considere estar apenas "num bom caminho" - e talvez por isso mesmo - a riqueza e a complexidade do tema escolhido, aliadas à riqueza na percepção dos sujeitos, vão além desta pesquisa.

É preciso indicar estudos: pesquisas com outros docentes da área contábil; a comparação e a análise entre as práticas interdisciplinares e os projetos pedagógicos das IES; a contraposição entre as práticas pedagógicas interdisciplinares e a legislação nacional e internacional; a comparação das prerrogativas profissionais estabelecidas pelos órgãos de classe e as determinações de organismos nacionais e internacionais para uma discussão plena do papel do Contador, aliadas aos conhecimentos oriundos de outras Ciências ou áreas de conhecimento; o relacionamento da existência ou não da Interdisciplinaridade nas práticas pedagógicas de professores dedicados à docência e pesquisa com aqueles que exercem outras atividades profissionais.

Nesse cenário de mudanças e experimentações metodológicas, colocam-se novas exigências à discussão pedagógica. Não há um único caminho, é preciso 
conviver com a multiplicidade de práticas e de olhares, além de se conviver com a não neutralidade da ciência e dos métodos pedagógicos.

$\mathrm{O}$ ato pedagógico, de caráter essencialmente formativo, determina aprendizagens científicas, conhecimentos técnicos, valores e modelos de comportamento social. Construir e explicitar o projeto pedagógico de cada curso é uma tarefa necessária à efetivação de um processo de formação profissional consequente. E a construção desse projeto não pode prescindir da percepção crítica da função social da Universidade e do compromisso político e ético do trabalho docente, nem da discussão epistemológica e da análise crítica dos paradigmas que orientam os processos de seleção, organização, construção e socialização dos conhecimentos nas várias situações do contexto universitário.

Conclui-se que a interdisciplinaridade corresponde a uma nova consciência da realidade, a um novo modo de pensar, que resulta em um ato de troca, de reciprocidade e integração entre áreas diferentes de conhecimento, visando tanto à produção de novos conhecimentos, como à resolução de problemas, de modo global e abrangente. Os resultados obtidos indicam a necessidade de maior discussão do tema, relevante para uma melhor formação profissional e para a evolução da Ciência Contábil.

\section{REFERÊNCIAS}

BARDIN, L. Análise de Conteúdo. Lisboa: Edições 70, 2004.

BIASOLI ALVES, Z. M. M., DIAS DA SILVA, M.H.G.F. Análise qualitativa de dados de entrevista: uma proposta. Paidéia, Ribeirão Preto, n. 2, fev./jul, 1992.

BLOOM, R.; SOLOTKO, J. Using an historical account book as a teaching tool. Accounting Education, Oxfordshire, v. 14, n. 3, p. 239-268, Sept. 2005.

BRASIL. Lei nº 9.394/96 de 20 de dezembro de 1996: Lei de Diretrizes e Bases da Educação Nacional. Diário Oficial da República Federativa do Brasil, Brasília, DF, no. 248, p. 27.833-27.841, dez. 1996.

CATELli, A. (Coord.). Controladoria: uma abordagem da gestão econômica. GECON. São Paulo: Atlas, 1999.

CHAVES, A. O ciclo de formação geral e a reforma do ensino superior. [2007]. Disponível em: <http://www.educacao.gov.br/reforma/Documentos/ ARTIGOS/2005.3.7.17.4.56.pdf>. Acesso em: 30 mar. 2007. 
FAZENDA, I. C. A. Interdisciplinaridade: história, teoria e pesquisa. 2. ed. São Paulo: Papirus, 1995.

. Interdisciplinaridade: um projeto em parceria. 5. ed. São Paulo:

Loyola, 2002.

1996.

.(Org.). Práticas interdisciplinares na escola. São Paulo: Cortez,

FAZENDA, I. C. A. Integração e interdisciplinaridade no ensino

brasileiro: efetividade ou ideologia. São Paulo: Loyola, 1979.

FRANCO, M. L. P. B. Análise do conteúdo. Brasília: Liber Livro, 2005.

FRIGOTTO, G. A interdisciplinaridade como necessidade e como problema nas ciências sociais. In: JANTSCH, Ari Paulo; BIANCHETTI, Lucídio (Orgs.). Interdisciplinaridade: para além da filosofia do sujeito. Petrópolis: Vozes, 1995.

GADOTTI, M. A organização do trabalho na escola: alguns pressupostos. São Paulo: Ática, 1993.

- Interdisciplinaridade: atitude e método. São Paulo: Instituto Paulo Freire. Disponível em: <www.paulofreire.org>. Acesso em: 26 dez. 2006.

Paulo: Ática, 1993.

. A organização do trabalho na escola: alguns pressupostos. São

GIL, A. C. Como elaborar projetos de pesquisa. São Paulo: Atlas, 2002.

GUSDORF, G. Professores para que? Lisboa: Morais, 1967.

JANTSCH, A. P.; BIANCHETTI, L.. Interdisciplinaridade e práxis

pedagógica: tópicos para discussão sobre possibilidades, limites, tendências e alguns elementos histórico e conceituais. Ensino em Revista, Uberlândia, v. 10, n. 1, p. 7-25, 2002.

JAPIASSU, H. Interdisciplinaridade e patologia do saber. Rio de Janeiro: Imago, 1976.

KANITZ, S. C. Controladoria: teoria e estudo de casos. São Paulo: Pioneira, 1976.

KLEIN, J. T. Interdisciplinarity: history, theory \& practice. Detroit: Wayne State University Press, 1990.

LAVILLE, C.; DIONNE, J. A construção do saber: manual de metodologia de pesquisa em Ciências Humanas. Porto Alegre: Artmed, 1999. 
LEIS, H. R. Sobre o conceito de interdisciplinaridade. Florianópolis, ago. 2005 (Caderno de Pesquisa interdisciplinar em Ciências Humanas; 73).

LUCK, H. Pedagogia da interdisciplinaridade. Fundamentos teórico - metodológicos. Petrópolis: Vozes, 2001.

LÜDKE, M., ANDRÉ, M. E. D. A. Pesquisa em educação: abordagens qualitativas. São Paulo: EPU, 1986.

MANN, S. Interdisciplinarity for the University of Ottawa. Disponível em $<$ http://www.uottawa.ca/vr-etudes-academic/en/reports/RapportInterEng. pdf $>$. Acesso em: 12 jan. 2007.

MARION, J. C. O ensino da contabilidade. São Paulo: Atlas, 1996.

MIRANDA, C.; MIRANDA, R. A. M. Interdisciplinaridade e métodos de ensino no curso de contabilidade: um estudo no nordeste paulista. In: CONGRESSO USP DE CONTROLADORIA E CONTABILIDADE, 6. 2006, São Paulo. Anais eletrônicos... Disponível em: $<$ http://www.congressoeac. locaweb.com.br/artigos62006/426.pdf>. Acesso em: 05 jan. 2007.

MICHELAT, G. Sobre a utilização da entrevista não diretiva em sociologia, criticas metodológica, investigação social e enquete operária. 3. ed. [s.1.]: Polis, 1982.

MOLINARI, S. K. R., Contabilidade, psicologia e sociologia: uma análise interdisciplinar para profissionais diferenciados. In: CONGRESSO USP DE CONTROLADORIA E CONTABILIDADE, 3., 2003, São Paulo, Anais eletrônicos... Disponível em: <http://www.congressoeac.locaweb.com.br/ artigos32003/default.asp/>. Acesso em: 05 jan. 2007.

MORAES, M. C. O paradigma educacional emergente. São Paulo: Papirus, 2002.

MORIN, E. Os sete saberes necessários à educação do futuro. 2. ed. São Paulo. Cortez, 2000.

Educação e complexidade, os sete saberes e outros ensaios.

São Paulo: Cortez, 2005.

NASCIMENTO, A. M.; REGINATO, L. A aplicação dos conceitos de Controladoria conjugados aos de tecnologia da informação como apoio ao processo decisório. In: CONGRESSO BRASILEIRO DE CUSTOS, 13, 2006, Belo Horizonte, MG. Anais... Belo Horizonte: Associação Brasileira de Custos, 2006. 1 CD ROM. 
NISSANI, M. Interdisciplinarity: what, where, why? Disponível em: $<$ www.is.wayne.edu/mnissani/PAGEPUB/ispessav.htm>. Acesso em: 04 set. 2006.

PADOAN, F. A. C., CLEMENTE, A. A interdisciplinaridade no ensino da Contabilidade - um estudo empírico da percepção dos docentes. In: CONGRESSO USP DE CONTROLADORIA E CONTABILIDADE, 6., 2006, São Paulo. Anais eletrônicos... Disponível em: <http://www. congressoeac.locaweb.com.br/artigos62006/551.pdf>. Acesso em: 10 jan. 2007.

PAIVA, S. B. O ensino da Contabilidade: em busca da interdisciplinaridade. Revista Brasileira de Contabilidade, Brasília, v. 28, n. 120, p. 89-93, 1999.

PASSOS, I. C. A interdisciplinaridade no ensino e na pesquisa contábil: um estudo no município de São Paulo, 2004. Dissertação (Mestrado em Controladoria e Contabilidade) - Faculdade de Economia, Administração e Contabilidade, Universidade de São Paulo, São Paulo, 2004.

PELEIAS, I. R. Controladoria: Gestão eficaz utilizando padrões. São Paulo: Saraiva, 2002.

PELEIAS, I. R.; SINATORA, J., R., P.; SILVA, D.; FARIA, A.C. Análise das condições de oferta da disciplina sistemas de informação: pesquisa com cursos de Ciências Contábeis na cidade de São Paulo. In: LOPES,J.; RIBEIRO FILHO, J. F.; PEDERNEIRAS, M. Educação contábil: tópicos de ensino e pesquisa. São Paulo: Atlas, 2008.

PINHEIRO, E. J. Sistema didático interdisciplinar para o curso de ciências contábeis. In: FÓRUM NACIONAL DE PROFESSORES DE CONTABILIDADE, 4., 2003, Gramado, RS.

PIAGET, J. Para onde vai a educação? Rio de Janeiro: José Olympio, 1973.

POMBO, O. Epistemologia da interdisciplinaridade. In: SEMINÁRIO INTERNACIONAL INTERDISCIPLINARIDADE, HUMANISMO, 2003, Porto. Porto: Faculdade de Letras da Universidade do Porto, 2003.

POMBO, O. (Org.). Contribuição para um vocabulário sobre interdisciplinaridade. Liinc em revista, Rio de Janeiro, v. 1, n. 0, mar. 2005. Disponível em: <http://www.liinc.ufrj.br/revista>. Acesso em: 10 fev. 2006. 
ROSA. M. V. F. P. C; ARNOLDI. M. A. G. C.; A entrevista na pesquisa qualitativa: mecanismos para avaliação dos resultados. São Paulo: Autêntica, 2006.

SCHWARTZMAN, S. O Sentido da Interdisciplinaridade. Novos estudos CEBRAP, São Paulo, n. 32, p. 191-198, mar. 1992. Disponível em: <http:// www.schwartzman.org.br/simon/redesc/interdis.htm>. Acesso em: $20 \mathrm{dez}$. 2005.

SILVA, A. C. R. Interdisciplinaridade nos cursos de ciências contábeis: isso é possível? Um relato de experiência. In: FÓRUM NACIONAL DE PROFESSORES DE CONTABILIDADE, 4., 2003, Gramado, RS.

SIQUEIRA, H. S. G. Formação interdisciplinar: exigência sócio-política para um mundo em rede. In: SIMPÓSIO ESTADUAL DE ECONOMIA DOMÉSTICA, 7., 2003, Francisco Beltrão, PR. Anais eletrônico... Francisco Beltrão, PR: UNIOESTE, 2003. Disponível em: <http://www. angelfire.com/sk/holgonsi/mundorede.html >. Acesso em 25 nov. 2006.

TRIVIÑOS, A.N.S. Introdução à pesquisa em ciências sociais. São Paulo: Atlas, 1987.

VATTER, W. J. Accounting education for controllership. The Accounting Review, Sarasota, v. 25, n. 3, p. 236-250, July 1950.

VEIGA, I. P. A. Projeto Político-Pedagógico: continuidade ou transformação para acertar? In: CASTANHO, S.; CASTANHO, M. E. (Orgs.). O que há de novo na educação superior: do projeto pedagógico à prática transformadora. Campinas: Papirus, 2000.

VEIGA, I. P. A. (Org.). Projeto Político-pedagógico da escola: uma construção possível. Campinas, SP, Papirus, 1995.

VEIGA, I. P. A. Lições de Didática. São Paulo: Papirus, 2006.

VYGOTSKY, Lev. Pensamiento y lenguaje. Buenos Aires: La Pléyade, 1986.

WALKER, S.P. Accounting in history. Accounting Historians Journal, Tuscaloosa, v. 32, n. 2, p. 233-259, Dec. 2005. 